\title{
Assessment of post-mining terrain suitability for economic use
}

\author{
P. Strzałkowski ${ }^{1}$ (D) R. Ścigała ${ }^{1}$ (I)
}

Received: 20 April 2019 / Revised: 14 November 2019 / Accepted: 29 December 2019 / Published online: 16 January 2020

(c) The Author(s) 2020

\begin{abstract}
Upper Silesian Coal Basin in Poland is subjected to underground mining for several hundreds of years. Due to intensive extraction, land surface has been widely transformed, causing a lot of mining damages. Of great importance is the issue of recovering the surface to its previous conditions after mining activity is finished. In specific conditions, a threat of mining damages may rest for several years after mine closure. In this paper, some chosen issues connected with assessment of postmining terrain suitability for economic use have been discussed. Two important elements of such threat have been described: determining the possibility of discontinuous deformations creation and the evaluation of active subsidence process duration. In the introductory part of the paper some theoretical base has been given. Next, the example of probability assessment of sinkhole creation has been presented, together with determination of subsidence process cease time. For determination of subsidence process duration, own empirical formulas have been utilized. They can be used in cases, when there is a lack of survey results from the area of interest.
\end{abstract}

Keywords Continuous deformations $\cdot$ Discontinuous deformations $\cdot$ Mine closure $\cdot$ Mining subsidence

\section{Introduction}

Mining activity, due to the operation on non-renewable resources of useful minerals, is characterized by a defined period of existence of any investment project. Due to the significant impact of mining on the natural environment causing its transformation, of very importance is the reclamation of mining areas after mine closure. This problem was widely discussed in the past, as well as present works-one can find interesting issues, e.g., in the works (Lin et al. 1990; Zhao et al. 2015; Işleyen et al. 2017; Contrucci et al. 2019).

Geological processes take place in mining areas, both active and liquidated mines, but also in areas not covered by mining activities (Whittaker and Reddish 1989; Bell and Donnelly 2006). They create in many cases a significant threat to public safety. The problem is of particular importance in case of areas with a high degree of urbanization. For example, karst phenomena occurring in many countries

Editorial responsibility: Zhenyao Shen.

R. Ścigała

roman.scigala@polsl.pl

1 Faculty of Mining, Safety Engineering and Industrial Automation, Silesian University of Technology, Akademicka 2, 44-100 Gliwice, Poland in carbonate rocks may cause the formation of sinkholes, e.g., in Florida in the USA, which was described, among others, in Xiao et al. (2016). The loss of stability of caverns existing at shallow depths may be caused also by seismic shocks, for example, in case of near Athens locations, presented in work Papadopoulou-Vrynioti et al. (2013). So, the possibility of sinkhole creation is influenced by many factors associated with geological and hydrogeological conditions, land morphology, and the amplitude of vibrations acceleration caused by shocks (natural or human-induced). In the paper Bathrellos et al. (2012), it has been methodology proposed for integrated assessment of areas suitable for urban and light industry development, taking into account natural hazards as well as geological and geomorphological-geographical conditions of the research area. In the work Xiao et al. (2016), a strong correlation was confirmed between the intensity of precipitation and the moment of sinkhole creation. It was also determined that the number of created sinkholes (areal density) increases linearly with the increase in aquifers water supply rate.

Apart from land surface deformations, ecological and health issues are of great significance (Weyer et al. 2019; Ciszewski 2019; Palma et al. 2019), as well as social problems (Kowalska-Jonek 2014; Marais et al. 2018; Everingham et al. 2018; Kivinen et al. 2018). 
As it was mentioned earlier, geological threats very often are connected with transformations caused by mining activity. It was noted in the work Dobak et al. (2009) that in postmining areas the most important problems for inhabitants and urban infrastructure are connected with:

- sinkholes due to cave-in of shallow roadways and shafts,

- discontinuous deformations tied with extraction led in several seams to the same border, especially in the vicinity of fault outcrops,

- continuous deformations in the form of subsidence troughs and their derivatives (Knothe 1953; Kratzsch 1983; Whittaker and Reddish 1989; Orwat and Mielimąka 2015),

- changes of local water conditions inside the rockmass,

- release of fire gases migrating from shallow gobs through the fractured rockmass.

Presented in the paper considerations based on the results of research carried out in most Polish Upper Silesian Basin coal mines during the period between years 2000 and 2018 .

\section{Materials and Methods}

\section{The characteristics of chosen factors influencing the economic usability of post-mining terrain}

In post-mining areas in Poland, the most important transformations determining the suitability of such land for development are continuous deformations occurring on the surface for a certain period of time after the end of extraction and discontinuous deformations arising mainly due to the existence of shallow voids being usually a direct or indirect effect of old mining activity.

In connection with the above, the following are the most important elements of the assessment of the economic usefulness of post-mining areas:

- determination of the duration of the deformation process after finishing of mining activity,

- assessment of threat level caused by sinkhole arising possibility.

\section{Estimation of the duration of subsidence process}

For obvious reasons, the construction of new facilities in mining areas should start after the subsidence process caused by underground mining is completely finished. Determining whether a given area is subjected to the active deformation process can be most objectively based on the results of geodetic measurements. However, for various reasons, they are not always carried out over the whole mining terrain. In such cases, one can utilize empirical formulas worked out for given mining geological conditions. Such formulas may also be useful in cases of determining the subsidence process finish time for the newly planned extraction.

The deformation process lasts during the extraction is led and sometime after it is finished (Karfakis 1993; Chudek et al. 2000). Because extraction start time and finish time are known, important is from practical point of view the period necessary for all mining-induced surface movements to be finished ("subsidence cease time"). This period should be understood as time interval between extraction finish and subsidence process end. In the work Chudek et al. (2000), empirical formula was proposed, valid for Polish Upper Silesian Basin conditions for extraction led with caving:

$T_{\mathrm{k}}=0.015 \frac{H}{(\operatorname{tg} \beta)^{0.5}}+2.394$

where $T_{\mathrm{k}}$-the subsidence cease time, months, $H-$ the extraction depth, meters, $\operatorname{tg} \beta$-the parameter of Budryk-Knothe theory describing influence range (Knothe 1953).

This formula is the result of statistical analyses based on the results of subsidence measurements performed only on a limited number of observation lines. Further research carried out by the authors based on a more reach data set (the results of measurements carried out on 54 observation lines located in the mining area of 16 Upper Silesia Basin mines were analyzed) allowed to clarify the dependence (1). The land area covered by research is presented in Fig. 1. Finally, in the paper Strzałkowski and Ścigała (2010), the following formula was proposed:

$T_{\mathrm{k}}=0.042 \frac{H^{0.948}}{(\operatorname{tg} \beta)^{0.609}}$

Above formula is valid for the following range of input data:

- extraction led with caving,

- the extraction depth: 270-840 m,

- the extraction front rate: $3-5 \mathrm{~m} / \mathrm{day}$.

Aiming at simplification of formula (2), the following dependence was proposed:

$T_{\mathrm{k}}=0.028 \frac{H}{(\operatorname{tg} \beta)^{0.5}}$.

The meaning of variables used in the above equation is identical to (1) and (2).

It should also be noted that for all mines considered in the research, individual analyses were conducted to determine the duration of the final phase of the deformation 


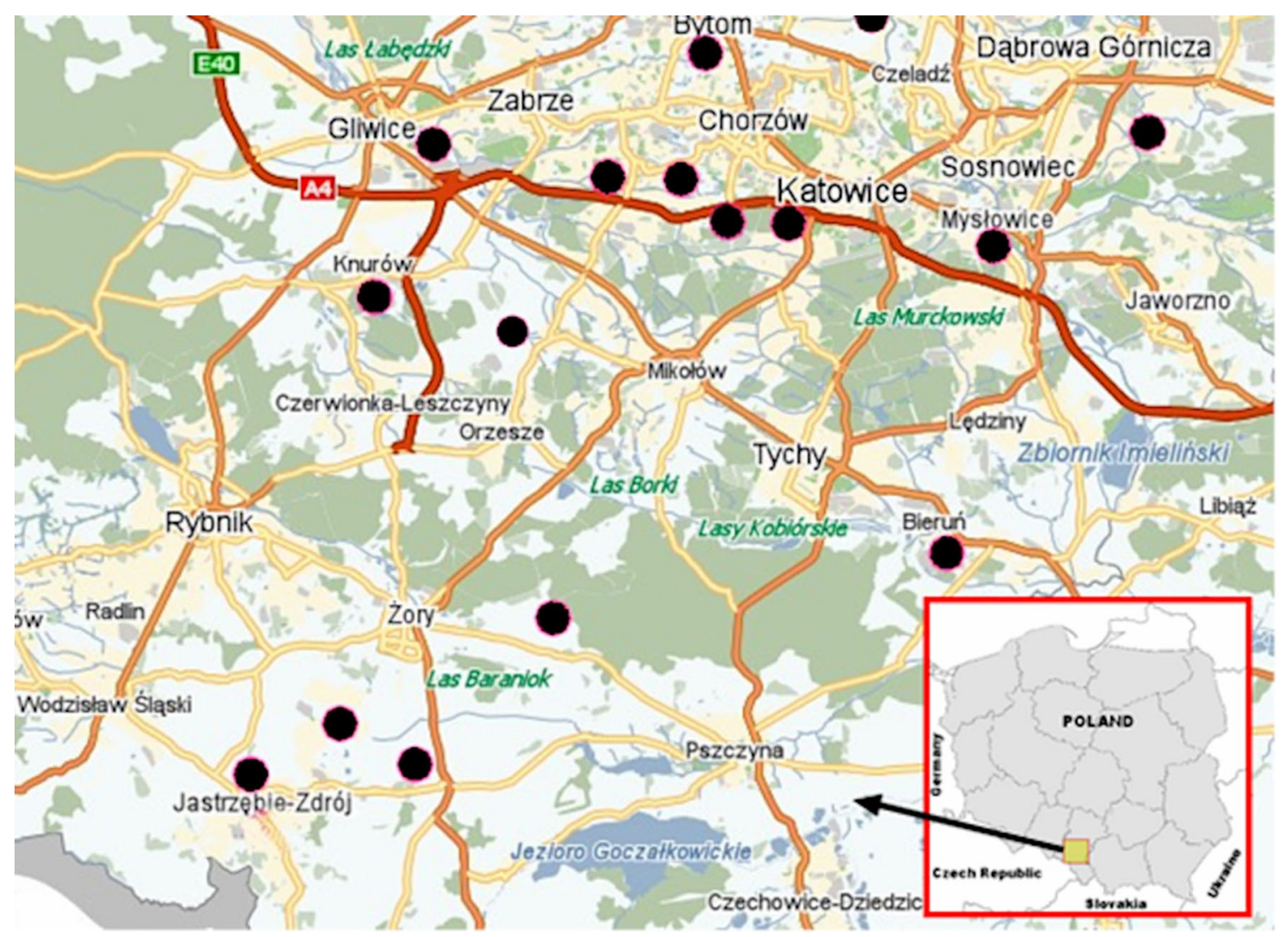

Fig. 1 The research area. The locations of mines for which analyses have been carried out are marked with big black dots on the figure

process depending on the extraction depth, assuming that the remaining factors affecting this time are constant under given geological and mining conditions.

An example of such an analysis, carried out for the conditions of the mine not included in the analyses, that led to the development of formulas (1)-(3) is shown below. In Table 1, the extraction depth is given, which caused the subsidence recorded along a given observation line, as well as the duration of the final deformation phase determined on the basis of measurements $-T_{\mathrm{k} \text { meas }}$ and $T_{\mathrm{k}}$, worked out on the basis of formulas (1)-(3). In addition, the equation of regression line (4) is given, which was developed for the considered mine conditions. The calculated value of the subsidence cease time is marked in Table 1 as $T_{\mathrm{k}}$ (4). The regression line of obtained course of $T_{\mathrm{k}}$ versus depth of extraction is shown in Fig. 2.

$T_{\mathrm{k}}=0.0394 H-15.263$.

Due to the fact that the above case was not taken into account in the statistical analyses that led to the development of formulas (1)-(3), an opportunity was created to compare the values obtained from the considered formulas (1)-(3) with the results obtained on the basis of measurement results in the analyzed given case-see Table 1 . As can be seen from this table, the best agreement with the measurement
Table 1 Duration of the final phase of the deformation process depending on the depth of extraction for the geological and mining conditions of the analyzed coal mine

\begin{tabular}{llllll}
\hline $\begin{array}{l}\text { Extraction } \\
\text { depth } H[\mathrm{~m}]\end{array}$ & \multicolumn{5}{l}{ Subsidence cease time $T_{\mathrm{k}}$} \\
\cline { 2 - 6 } & $T_{\mathrm{k} \text { meas }}[\mathrm{months}]$ & $T_{\mathrm{k}}(1)$ [months] & $T_{\mathrm{k}}(2)$ [months] & $T_{\mathrm{k}}(3)$ [months] & $T_{\mathrm{k}}(4)$ [months] \\
\hline 670 & 12 & 9.5 & 13.2 & 13.3 & 11.1 \\
745 & 13 & 10.3 & 14.5 & 14.8 & 14.1 \\
790 & 15.5 & 10.8 & 15.4 & 15.6 & 15.9 \\
840 & 17 & 11.3 & 16.3 & 16.6 & 17.8 \\
860 & 20 & 11.5 & 16.7 & 17.0 & 18.6 \\
\hline
\end{tabular}


Fig. 2 The depth of extraction versus duration of the final phase of the deformation process determined on the basis of the measurement results and the linear regression function approximating the data

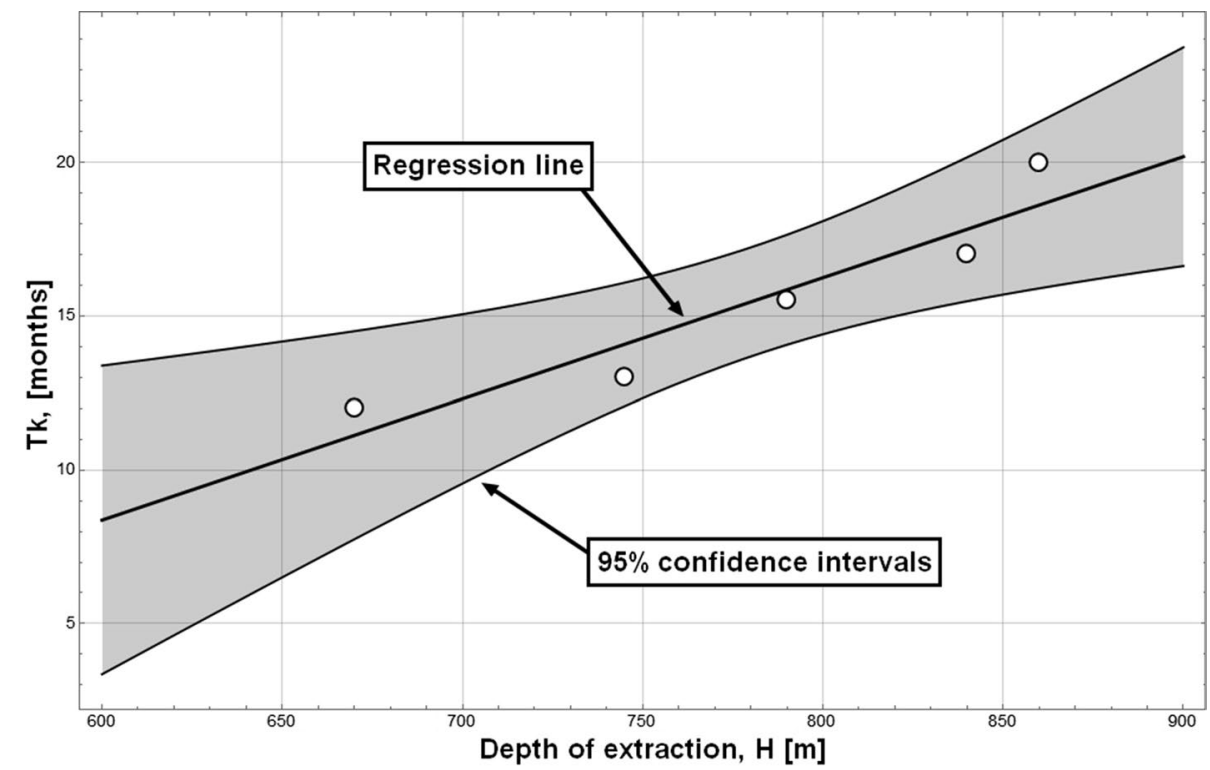

results was obtained using the formula (4), developed only for the conditions of the considered mine. The comparison of subsidence cease time determined on the basis of formulas (1)-(4) with obtained from survey results is shown in Fig. 3.

\section{Results and discussion}

\section{The assessment of threat level connected with sinkhole creation hazard}

The occurrence of the sinkholes is caused by the transition into a cave-in zone of shallow voids formed inside the rock mass due to natural processes or as a result of mining activity (Chudek et al. 1988; Taylor et al. 2000; Sahu and Lokhande 2015; Salmi et al. 2019). The phenomena inducing their formation have, for various reasons, to a large extent, a random character. In the conditions of Upper Silesia Basin in Poland, based on previous experiences, it is assumed that the hazard arises, when voids are located to a depth of about 80-100 m. Another important factor that often causes this threat is the occurrence of poorly liquidated or non-liquidated shafts (Bell 1988).

Due to the aforementioned contribution of random factor, forecasting of the sinkholes is a very difficult taskuntil today, no comprehensive method has been developed allowing the unambiguous determination of the possibility of such deformation arising on the surface. Presently, analytic-empirical methods are used for this purpose (Chudek
Fig. 3 The comparison of subsidence cease time determined on the basis of formulas (1)-(4) with obtained from survey results $-T_{\mathrm{k} \text { meas }}$

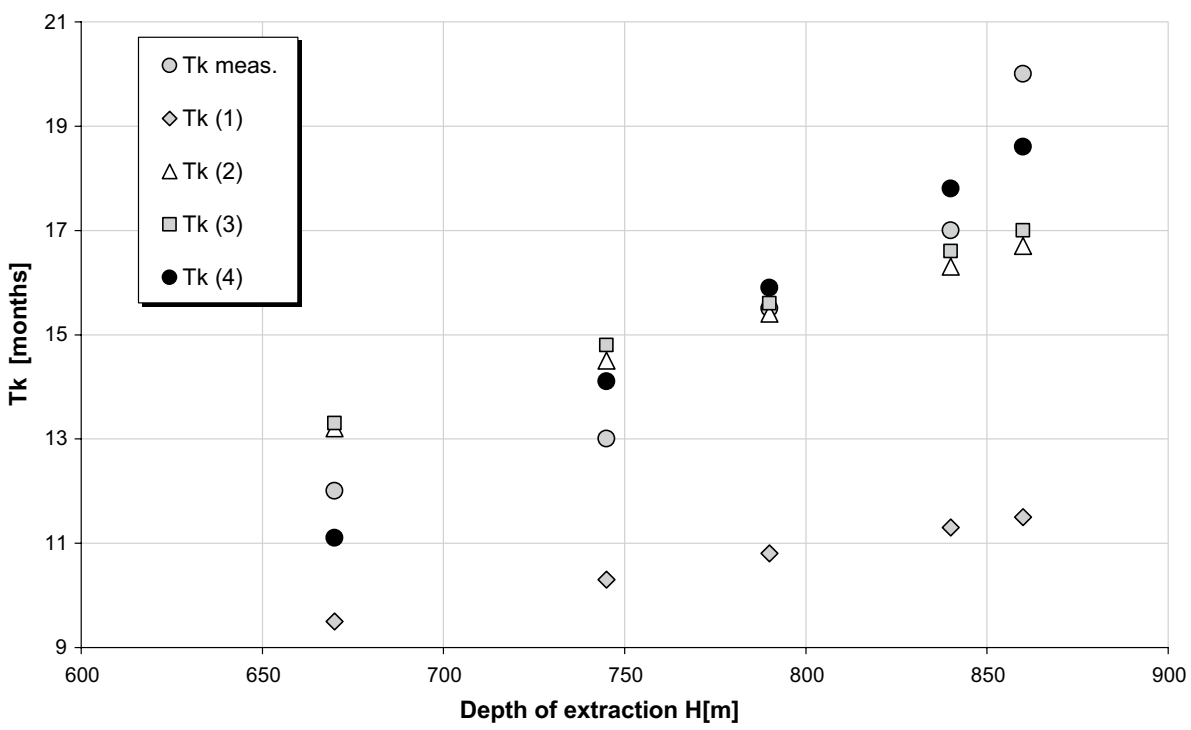


et al. 1988), but different numerical methods are under development (Tajdus and Sroka 2007). The existing solutions usually allow to determine the probability of a sinkhole creation and its average size. One of the methods of predicting the sinkhole hazard used in Poland is the method of M. Chudek-W. Olaszowski (Chudek et al. 1988). This method in its simplified version (convenient for use in case of incomplete information on given geological and mining conditions) allows to determine the probability of sinkhole formation, predicted average and maximum diameters, and their probable density per square kilometer. This probability is determined based on the value of the $Z$ index expressed by the formula:

$Z=\frac{H-h}{g}$,

where $H$-the depth of the void's roof, m; $h$-the thickness of loose overburden layers, $\mathrm{m} ; \mathrm{g}$ - the height of void, $\mathrm{m}$.

On the basis of the $Z$ index value, one can determine the probability value $P$ of sinkhole arising using the formula:

$P(Z)=1.34-0.036 \cdot Z+0.00019 \cdot Z^{2}$.
The authors of this solution have also developed special nomograms that allow convenient determination of the sinkhole's parameters to be sought. They can be found, inter alia, in Chudek et al. (1988).

\section{The exemplary assessment of post-mining terrain suitability for economic use}

The following is a practical example of the implementation of the two elements of the assessment of suitability for developing the post-mining area. The data from the area of the same coal mine were used, for which analyses were carried out to develop the formula (4).

The rock mass in the considered area is built of quaternary overburden with an average thickness of about $5 \mathrm{~m}$ and is represented by layers of clay, sands, and gravels. Carbon is present in the form of the following layers: "laziskie," "orzeskie," "rudzkie," "siodłowe," and "porębskie" (according to Polish classification of carboniferous layers). They are formed from alternating sandy, clayey shales, and sandstone layers.
Table 2 Basic mininggeological data concerning last carried out extraction

\begin{tabular}{llllll}
\hline Coal seam no. & Longwall no. & Extraction start date & Extraction end date & $\begin{array}{l}\text { Thickness of } \\
\text { coal seam } g \\
{[\mathrm{~m}]}\end{array}$ & $\begin{array}{l}\text { Extraction } \\
\text { depth } H \\
{[\mathrm{~m}]}\end{array}$ \\
\hline 501 & 505 & $01-08-2017$ & $30-06-2018$ & 3.0 & 820 \\
501 & 506 & $01-09-2016$ & $30-04-2017$ & 3.2 & 815 \\
501 & 507 & $01-02-2015$ & $31-03-2016$ & 3.2 & 800 \\
$510 \mathrm{w} 3$ & $44 \mathrm{a}$ & $01-07-2010$ & $31-12-2010$ & 2.5 & 737 \\
$510 \mathrm{w} 3$ & 555 & $01-10-2011$ & $31-07-2012$ & 2.4 & 750 \\
$510 \mathrm{w} 3$ & 556 & $01-01-2011$ & $31-01-2012$ & 3.0 & 739 \\
$510 \mathrm{w} 3$ & $556 \mathrm{a}$ & $01-06-2014$ & $30-09-2014$ & 2.5 & 762 \\
$510 \mathrm{w} 3$ & 557 & $01-01-2013$ & $30-06-2014$ & 3.0 & 784 \\
$510 \mathrm{w} 3$ & 558 & $01-11-2015$ & $30-09-2016$ & 3.0 & 784 \\
\hline
\end{tabular}

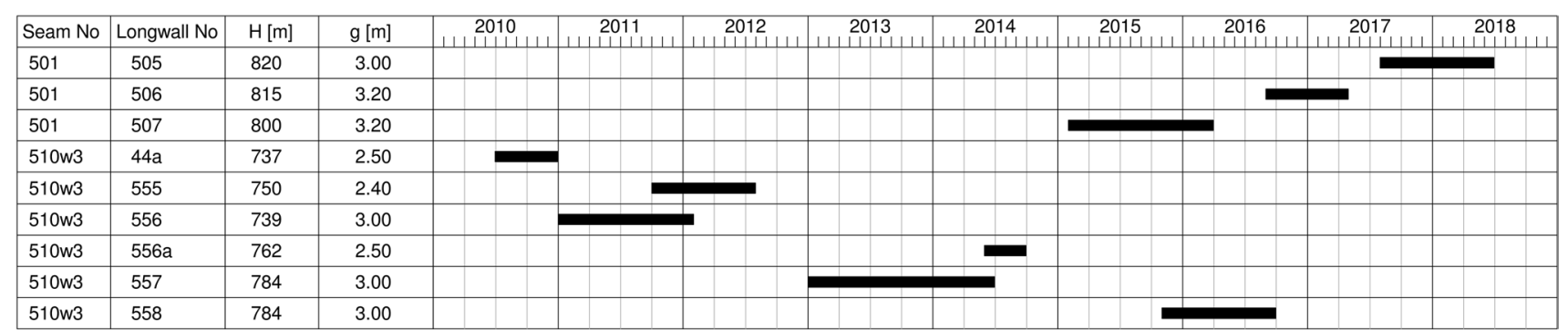

Fig. 4 The schedule of last carried out extraction in the area of interest 


\section{Determination of the time-space distribution of post-mining surface movements decay}

Data on geological and mining conditions of performed in the past extraction are summarized in Table 2. Two coal seams from "siodłowe" layers were subject to extraction: 501 and 510 with several longwalls. To illustrate the sequence of extraction over time, its schedule is presented in Fig. 4. The location of extracted longwalls is shown in Fig. 5, where extraction carried out in the seam 501 is marked with blue color and in 510 seam-with red. In this picture, old shallow workings are also marked in coal seam 318 to a depth of $0-50 \mathrm{~m}$ (green color) and to a depth of 50-100 m (violet color). Coal seam 318 was extracted with caving in the analyzed region in the period $1800-1925$ to the height of $1.0-2.5 \mathrm{~m}$.

Table 3 presents the results of the calculations of the duration of the final phase of the deformation process $\left(T_{\mathrm{k}}\right)$

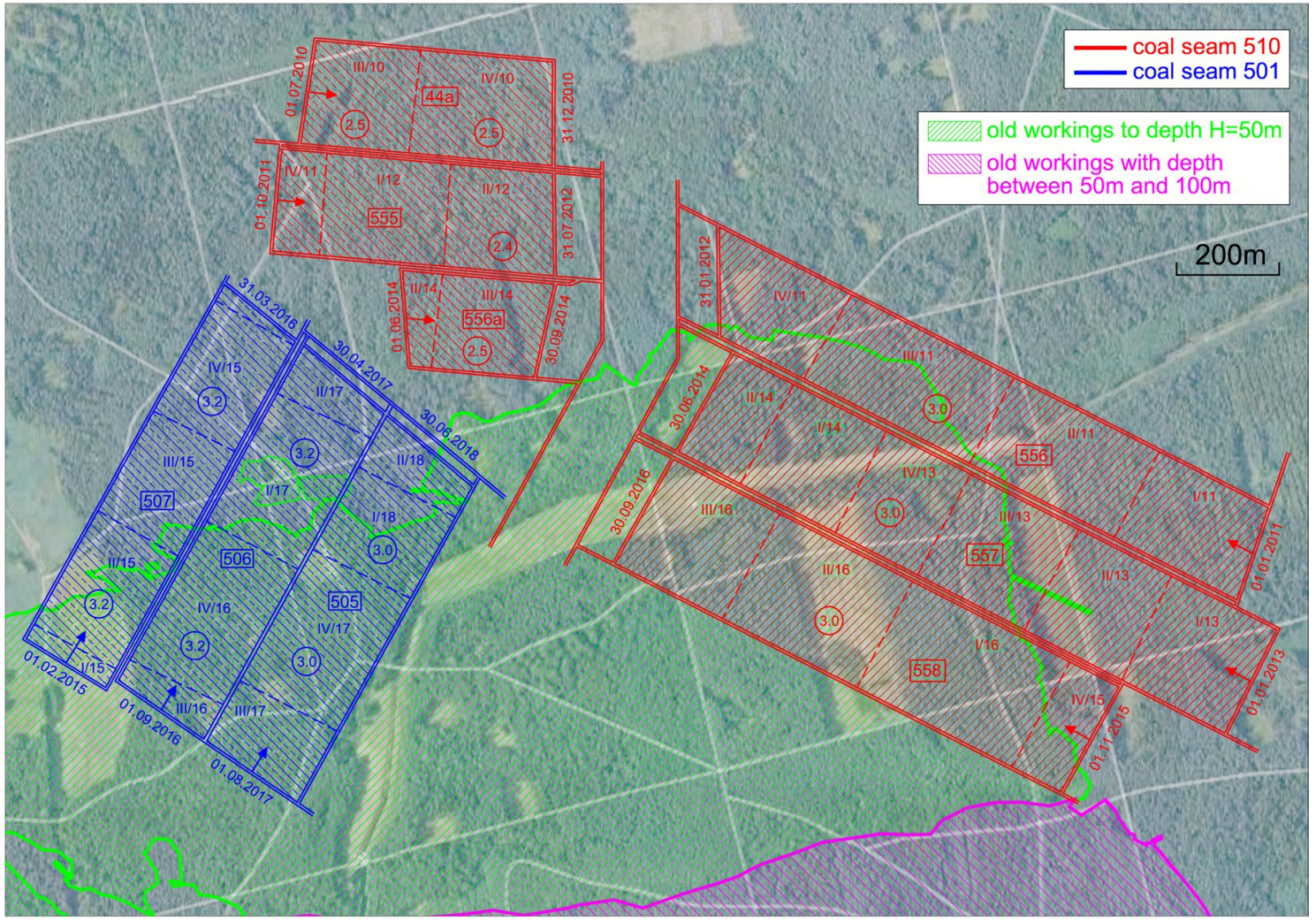

Fig. 5 Location of last carried out extraction on the background of old shallow workings

Table 3 The duration of the final phase of the deformation process $\left(T_{\mathrm{k}}\right)$ for individual extraction fields, calculated with formulas (1)-(4)

\begin{tabular}{llllll}
\hline Longwall no. & $\begin{array}{l}\text { Extraction } \\
\text { depth } H[\mathrm{~m}]\end{array}$ & $T_{\mathrm{k}}(1)$ [month] & $T_{\mathrm{k}}(2)$ [month] & $T_{\mathrm{k}}(3)$ [month] & $T_{\mathrm{k}}$ (4) [month] \\
\hline 505 & 820 & 11.1 & 15.9 & 16.2 & 17.0 \\
506 & 815 & 11.0 & 15.8 & 16.1 & 16.8 \\
507 & 800 & 10.9 & 15.6 & 15.8 & 16.3 \\
$44 \mathrm{a}$ & 737 & 10.2 & 14.4 & 14.6 & 13.8 \\
555 & 750 & 10.3 & 14.6 & 14.8 & 14.3 \\
556 & 739 & 10.2 & 14.4 & 14.6 & 13.9 \\
$556 \mathrm{a}$ & 762 & 10.5 & 14.9 & 15.1 & 14.8 \\
557 & 784 & 10.7 & 15.3 & 15.5 & 15.6 \\
558 & 784 & 10.7 & 15.3 & 15.5 & 15.6 \\
\hline
\end{tabular}




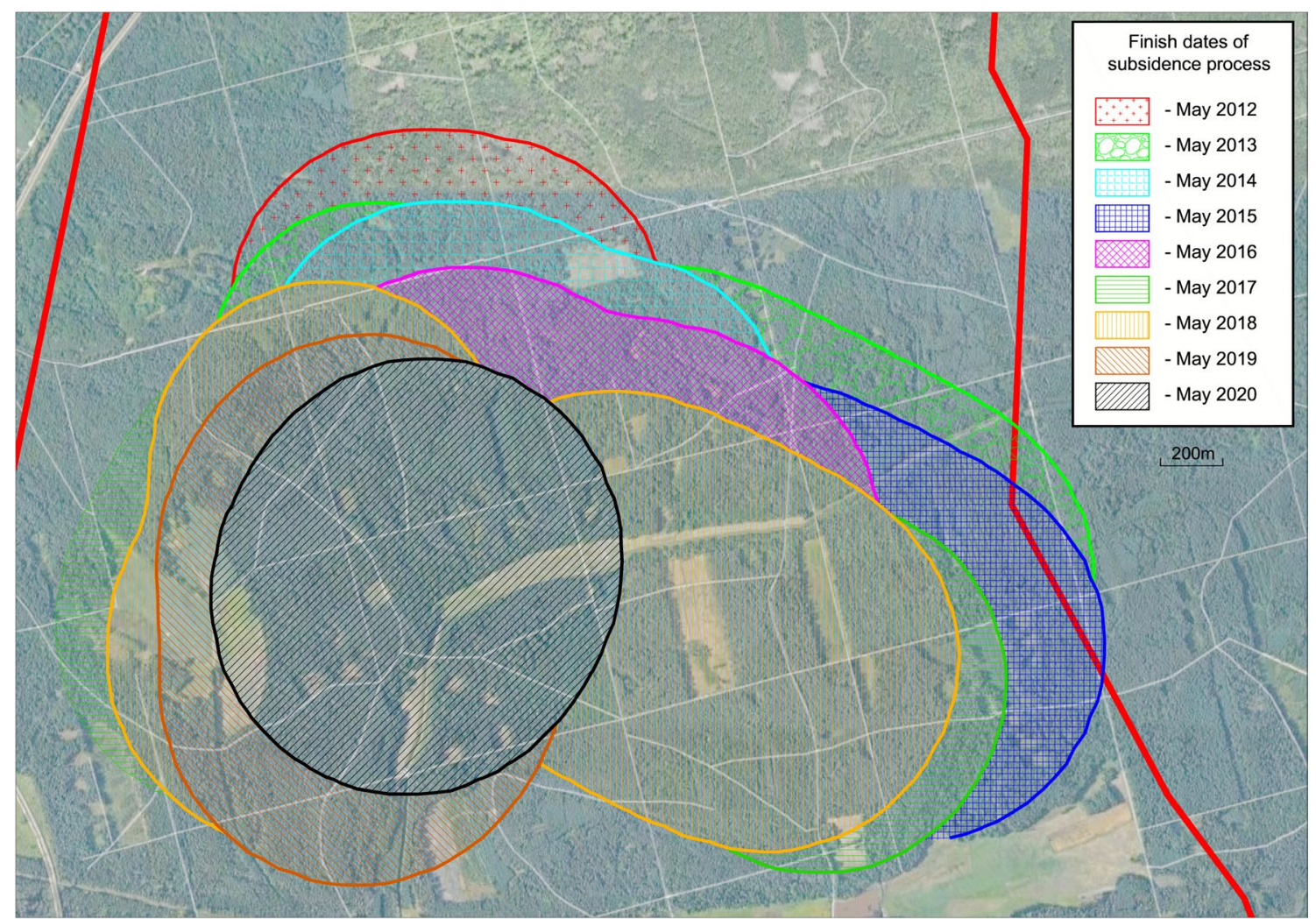

Fig. 6 Spatiotemporal distribution of areas with different moments of finishing the mining-induced subsidence process on the land surface, assuming $T_{\mathrm{k}}=17$ months

for individual extraction fields, according to data presented in Table 2 and Fig. 4. This time was calculated using the formulas (1)-(4), to present the diversity of $T_{\mathrm{k}}$ values calculated with different formulas.

It should be recognized that the results of calculations obtained using formulas (2)-(4) were very similar to each other. However, for further analyses, the results obtained using formula (4) were adopted as developed for the considered geological and mining conditions.

The obtained subsidence cease time $T_{\mathrm{k}}$ was used to develop a map of the spatiotemporal distribution of areas with different time of the subsidence process finish-Fig. 6 . This spatial variability is obviously related to the time and schedule of extraction shown in Fig. 4. The basis for the construction of such a map is to determine the influence ranges for fixed consecutive discrete time intervals. (In the presented example, annual time intervals have been used.) These influence ranges were determined using W. Budryk-S. Knothe theory (Knothe 1953; Kratzsch 1983), widely utilized in Polish mining industry for predictions of underground extraction influences on the surface. Calculations were performed using software named
DEFK-Win (Ścigała 2008). The following parameter values of Budryk-Knothe model were taken for the calculations:

- the coefficient of roof control for extraction with caving: $a=0.8$,

- the parameter describing the influence range: $\operatorname{tg} \beta=2.0$.

Having determined the spatial distributions of yearly influence ranges and $T_{\mathrm{k}}$ times from Table 3 , it was possible to develop the map presented in Fig. 6. The map shows the spatiotemporal distributions of subareas, where mininginduced subsidence process will be gradually decaying. For the approximation of subsidence cease moment in every subarea, the longest time calculated: $T_{\mathrm{k}}=17$ months was taken, on the basis of Table 3. In this way, we ensure that having some "safety factor," we give the information "when" and "were" the subsidence process will cease after finishing the extraction of consecutive longwalls in the area of interest. Presented map shows the time-discrete changes of subsidence process in annual intervals - of course, one can refine the map with shorter periods, e.g., every 3 months. In this case, it would be necessary to recalculate the influence 
ranges resulting from the extraction performed within 3 months time steps. But it should be kept in mind that longer time intervals give investors an additional safety factor ensuring that all mining-induced deformations are really finished for given subarea and the construction process may be started safely.

\section{Estimation of the probability of sinkhole creation above old shallow mining workings}

Due to lack of accurate information about the geological and mining conditions regarding the old, shallow mining extraction, it was only possible to determine the probability of the sinkhole occurrence. Assuming the least favorable case, when the height of the void equals the thickness of the extracted seam, the $Z$ index value can be calculated, and then the probability of the sinkhole creation in the grid of calculation points may be determined, which finally allows to generate a map of spatial distribution of this probability. Due to the limited volume of this work, as an example, the $P$ value for a single point was calculated, representing the average conditions for shallow old workings in the area of interest:

- the thickness of loose overburden layers: $h=5.0 \mathrm{~m}$,

- the height of the void: $g=2.0 \mathrm{~m}$,

- the depth of the roof of the void: $H=40 \mathrm{~m}$.

According to formula (5), $Z$ index value for above data equals: $Z=17.5$, so on the basis of formula (6), it gives the probability of sinkhole creation: $P=0.77$.

\section{Conclusion}

Underground mining extraction significantly transforms the land surface, creating difficulties and even risks when reusing it economically. Such a situation takes place even many years after the completion of mining works. The authors considered continuous and discontinuous deformations to be the most important factors related to transformations of post-mining areas.

In the case of continuous deformations, which manifest on the surface in the shape of subsidence troughs, an important element determining the economic use of post-mining areas is to determine the time necessary for deformation process to be finished, so that new investments carried out on the recovered land are not subjected to active mining impacts during the implementation of a given investment. In the case of discontinuous deformations (mainly sinkholes), it is important to identify the areas at risk and the probability of their occurrence. The considerations and analyses presented in this paper entitled to draw the following final conclusions:

1. The time necessary for finishing deformation process caused by performed or planned mining extraction in the absence of measurement results can be estimated using the empirical formulas, for example, those presented in the paper. The analyses carried out show, in particular, the usefulness of formulas (2) and (3). Under the conditions of a given mine, while even limited measurements were carried out, analyses aiming at determining formula valid for given local mining - geological conditions in the form of Eq. (4) - can be carried out.

2. Due to very frequent situations, where there is a lack of complete information concerning old shallow mining, it should be recognized that the risk of sinkhole formation may occur in the conditions, where mining workings are located at a depth of up to $100 \mathrm{~m}$. The probability of a sinkhole arising may be determined in such a case, among others, in the way presented in the work. In case of high probability value, the rock mass should be recognized with geophysical methods, and then having localized shallow voids, they should be filled-in for safe economic use of such post-mining terrain.

Acknowledgements The authors thankfully acknowledge the Silesian University of Technology, Poland, for providing all the facilities to perform the research work.

\section{Compliance with ethical standards}

Conflict of interest The authors declare that they have no conflict of interest.

Open Access This article is licensed under a Creative Commons Attribution 4.0 International License, which permits use, sharing, adaptation, distribution and reproduction in any medium or format, as long as you give appropriate credit to the original author(s) and the source, provide a link to the Creative Commons licence, and indicate if changes were made. The images or other third party material in this article are included in the article's Creative Commons licence, unless indicated otherwise in a credit line to the material. If material is not included in the article's Creative Commons licence and your intended use is not permitted by statutory regulation or exceeds the permitted use, you will 
need to obtain permission directly from the copyright holder. To view a copy of this licence, visit http://creativecommons.org/licenses/by/4.0/.

\section{References}

Bathrellos GD, Gaki-Papanastassiou K, Skilodimou HD, Papanastassiou D, Chousianitis KG (2012) Potential suitability for urban planning and industry development by using natural hazard maps and geological-geomorphological parameters. Environ Earth Sci 66(2):537-548. https://doi.org/10.1007/s12665-011-1263-x

Bell FG (1988) Land development. State of the art in location of old mine shafts. Bull Int Assoc Eng Geol 37:91-98. https://doi. org/10.1007/BF02590374

Bell FG, Donnelly LJ (2006) Mining and its impact on the environment. CRC Press, London

Chudek M, Janusz W, Zych J (1988) Studium dotyczące rozpoznania tworzenia się i prognozowania deformacji nieciagłych pod wpływem podziemnej eksploatacji złóż Transactions of Silesian University of Technology, Mining series, iss. 141 (in Polish)

Chudek M, Strzałkowski P, Ścigała R (2000) Czas trwania poeksploatacyjnych deformacji powierzchni terenu w zależności od warunków geologiczno-górniczych. Budownictwo Górnicze i Tunelowe 3:38-42 (in Polish)

Ciszewski D (2019) The past and prognosis of mining cessation impact on river sediment pollution. J Soils Sediments 19:393-402. https ://doi.org/10.1007/s11368-018-2015-2

Contrucci I, Balland C, Kinscher J, Bennani M, Bigarré P, Bernard P (2019) Aseismic mining subsidence in an abandoned mine: influence factors and consequences for post-mining risk management. Pure appl Geophys 176(2):801-825

Dobak P, Drągowski A, Frankowski Z, Frolik A, Kaczyński R, Kotyrba A, Pinińska J, Rybicki S, Woźniak H (2009) Zasady dokumentowania warunków geologiczno-inżynierskich dla celów likwidacji kopalń. Polish Ministry of Environment (in Polish)

Everingham J, Rolfe J, Lechner AM, Kinnear S, Akbar DA (2018) Proposal for engaging a stakeholder panel in planning post-mining land uses in Australia's coal-rich tropical savannahs. Land Use Policy 79:397-406. https://doi.org/10.1016/j.landusepol .2018 .08 .038

Işleyen E, Torun A, Düzgün HŞ (2017) Land use land cover change analysis for an abandoned surface coal mine. In: IMCET 2017: New trends in mining-Proceedings of 25th international mining congress of Turkey, pp 374-380

Karfakis MG (1993) Residual subsidence over abandoned coal mines. In: Hudson JA, Brown ET, Fairhurst C, Hoek E (eds)
Comprehensive rock engineering, vol 5. Pergamon Press, Oxford, pp 451-476

Kivinen S, Vartiainen K, Kumpula T (2018) People and post-mining environments: PPGIS mapping of landscape values, knowledge needs, and future perspectives in Northern Finland. Land Open Access J 7(4):151. https://doi.org/10.3390/land7040151

Knothe S (1953) The equation of finally formed profile of subsidence trough. Cracow Arch Min Metall 1(1):22-38

Kowalska-Jonek I (2014) Risk management in the hard coal mining industry: social and environmental aspects of collieries' liquidation. Resour Pol 41:124-134. https://doi.org/10.1016/j.resou rpol.2014.05.002

Kratzsch H (1983) Mining subsidence engineering. Springer, Berlin

Lin PM, Peng SS, Tsang P (1990) Dealing with subsidence on abandoned mine lands. Min Eng 42(11):1245

Marais L, Cloete J, Denoon-Stevens S (2018) Informal settlements and mine development: reflections from South Africa's periphery. J S Afr Ins Min Metall 118:1103-1111. https://doi.org/10.17159 /2411-9717/2018/v118n10a12

Orwat J, Mielimąka R (2015) The comparison of measured deformation indicators of mining area with theoretical values calculated using Knothe's formulas. In: Proceedings of the international conference on numerical analysis and applied mathematics (ICNAAM-2015). Book series: AIP conference proceedings, vol 1738, Article Number UNSP 080014. https://doi. org/10.1063/1.4951849

Palma P, López-Orozco R, Mourinha C, Lourdes Oropesa A, Novais $\mathrm{MH}$, Alvarenga $\mathrm{P}$ (2019) Assessment of the environmental impact of an abandoned mine using an integrative approach: a case-study of the "Las Musas" mine. Sci Total Env 659:84-94. https://doi. org/10.1016/j.scitotenv.2018.12.321

Papadopoulou-Vrynioti K, Bathrellos GD, Skilodimou HD, Kaviris G, Makropoulos K (2013) Karst collapse susceptibility mapping considering peak ground acceleration in a rapidly growing urban area. Eng Geol 158:77-88

Sahu P, Lokhande RD (2015) An investigation of sinkhole subsidence and its preventive measures in underground coal mining. Proc Earth Planet Sci 11:63-75. In: Conference: global challenges, policy framework and sustainable development for mining of mineral and fossil energy resources (gCPF2015)

Salmi EF, Karakus M, Nazem M (2019) Assessing the effects of rock mass gradual deterioration on the long-term stability of abandoned mine workings and the mechanisms of post-mining subsidence-a case study of Castle Fields mine. Tunn Undergr Space Technol 88:169-185

Ścigała R (2008) Komputerowe wspomaganie prognozowania deformacji górotworu i powierzchni wywołanych podziemną 
eksploatacją górniczą. Publishing House of Silesian University of Technology (in Polish)

Strzałkowski P, Ścigała R (2010) Determination of the duration of surface subsidence caused by underground extraction. Schriftenfreihe des Institutes fur Markscheidewewsen und Geodäsie an der Technischen Universitat Bergakademie Freiberg, pp 77-81

Tajduś K, Sroka A (2007) Analytic and numerical methods of sinkhole prognosis. In: Proceedings of the 7th Altbergbau-Kolloquium. Freiberg University of Mining and Technology, Germany, pp $152-156$

Taylor J, Fowell R, Wade L (2000) Effects of abandoned shallow bordand-pillar coal workings on surface development. Min Technol 109:140-145

Weyer V, deWaal A, Lechner AM, Unger CJ, O’Connor TO, Baumgartl T, Schulze R, Truter WF (2019) Quantifying rehabilitation risks for surface-strip coal mines using a soil compaction Bayesian network in South Africa and Australia: to demonstrate the R2 AIN framework. Integr Environ Assess Manag 15(2):190-208. https ://doi.org/10.1002/ieam.4128

Whittaker BN, Reddish DJ (1989) Subsidence occurrence, prediction and control. developments in geotechnical engineering. Elsevier, Amsterdam

Xiao H, Kim YJ, Nam BH, Wang D (2016) Investigation of the impacts of local-scale hydrogeologic conditions on sinkhole occurrence in East-Central Florida, USA. Environ Earth Sci 75:1274

Zhao YQ, Wang B, Li ZX, Li CP, Zhang L (2015) Overview of international mine closure practices for capability building in China. Legislation, Technology and Practice of Mine Land Reclamation-Proceedings of the Beijing International Symposium Land Reclamation and Ecological Restoration, pp 481-488 